\title{
Changes To Accounting For Defined Benefit Postretirement Plans: Discussion And Illustration
}

\author{
Norman H. Godwin, (E-mail: godwinh@auburn.edu), Auburn University
} Arlette C. Wilson, (E-mail: awilson@business.auburn.edu), Auburn University

\section{INTRODUCTION}

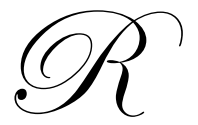

equests that the Financial Accounting Standards Board (FASB) address issues related to employers' accounting for defined benefit postretirement plans have increased in recent years. Those requests have been made by users of financial statements and others, including the Securities and Exchange Commission (SEC) staff and representatives of the Pension Benefit Guaranty Corporation. Constituents are interested in improved transparency and understandability.

Agreeing that the accounting for defined benefit postretirement plans should be reconsidered, the FASB added the project to its agenda in November 2005. The first phase of the project is complete and addresses the reporting of a plan's funded status. Under current rules, a plan's underfunded (overfunded) status is disclosed in the footnotes while only a portion of the liability (asset) is recognized on the balance sheet. Statement of Financial Accounting Standards No. 158 "Employers' Accounting for Defined Benefit Pension and Other Postretirement Plans" requires that the entire underfunded (overfunded) status of a plan be reflected on the balance sheet. This reporting is accomplished by requiring all changes in unrecognized prior service costs (credits), actuarial losses (gains), and transition obligation (asset), which are currently disclosed in the notes, to flow through other comprehensive income $(\mathrm{OCI})$ and be reported as part of a pension liability (asset).

The purpose of this paper is threefold. First, it identifies the basic changes from current accounting. Second, it provides comparative illustrations. Third, it discusses the potential impact on the financial statements.

\section{BASIC CHANGES}

Current pension accounting allows for delayed recognition of three items: actuarial gains/losses, prior service cost/credits associated with plan amendments, and transition obligation/asset remaining from the adoption of SFAS 87 and SFAS 106. The purpose of the delayed recognition is to create a smoothing effect on the pension expense reported in current earnings. When accumulated actuarial gains/losses exceed a calculated threshold, a portion of the amount exceeding the threshold is recognized in pension expense. Any remaining unrecognized balance is disclosed in the notes. Unrecognized prior service cost or transition obligation is recognized in pension expense as it is amortized. Any unrecognized balance is also reported in the notes. Accumulated actuarial gains/losses, unamortized prior service cost, and unamortized transaction obligation are included in a table reconciling the underfunded or overfunded status of the plan with the liability (asset) reported on the balance sheet.

The new requirements increase the visibility of the economic effects of postretirement benefits by including the previously unrecognized amounts on the balance sheet. In particular, any changes in actuarial gains/losses and prior service cost that are not included in pension expense will flow through Other Comprehensive Income (OCI). As you will see in the examples below, this has the effect of showing the plan's entire net obligation or asset on the financial statements rather than in the notes. Transitioning from the current approach to the SFAS 158 requires that Accumulated Other Comprehensive Income (AOCI) be adjusted for the balances in any unrecognized actuarial gains/losses, prior service cost/credits and transition obligation/asset as of the end of the fiscal year of initial application. If any of these unrecognized amounts is subsequently included in pension expense, those amounts will be reclassified from AOCI into current earnings. 
This new approach would result in the underfunded or overfunded status of a plan being reported on the balance sheet since all economic costs affecting the postretirement benefit plan would flow through comprehensive income either as pension expense or as OCI. Footnote disclosure is not an adequate substitute for recognition, so these changes should improve transparency and understandability of the employer's financial statements regarding the costs and obligations of providing postretirement benefits.

The effective date of these new requirements depends on whether the employer is an issuer of publicly traded equity securities. An employer with publicly traded equity securities should initially apply the requirement to recognize the funded status of a benefit plan as of the end of the fiscal year ending after December 15, 2006. An employer without publicly traded equity securities should initially apply the requirements as of the end of the fiscal year ending after June 15, 2007. Application as of the end of an earlier fiscal year is encouraged.

\section{COMPARATIVE ILLUSTRATIONS}

Two examples are used to provide a comparison between the current accounting and the proposed accounting as it relates to the pension asset or liability reported on the balance sheet. We assume that the employer has publicly traded equity securities and a December 31 year-end. Therefore, the transition will occur at December 31, 2006. The first example focuses on a situation in which a plan's underfunded obligation exceeds the liability currently reported on the balance sheet. The second example deals with a situation in which a plan's overfunded obligation nonetheless results in a liability on the current balance sheet. The comparative illustrations will show that the new accounting would actually result in the entire underfunded or overfunded status of the plan being reflected on the balance sheet as a pension liability or asset.

\section{Example 1}

Exhibit 1 contains information on a pension plan under current reporting requirements. We first see that the plan's underfunded balance, based on the projected benefit obligation, is $\$ 416,000$ in 2006 and $\$ 377,500$ in 2007 . We also see substantial unrecognized prior service cost and actuarial losses, both of which are disclosed in the notes. The total liability reported on the balance sheet is the sum of accrued pension cost and the additional minimum pension liability. This results in a reported liability balance of \$82,000 in 2006 and \$90,500 in 2007.

\section{EXHIBIT 1}

Pension Information For Example 1

\begin{tabular}{|c|c|c|}
\hline & $\underline{2006}$ & $\underline{2007}$ \\
\hline Projected Benefit Obligation (Jan. 1) & $\$ 676,000$ & $\$ 934,000$ \\
\hline Service Cost & 130,000 & 150,000 \\
\hline Interest Cost & 40,500 & 48,000 \\
\hline Payments & $(11,000)$ & $(15,000)$ \\
\hline (Gain) Loss & 98,500 & $(10,000)$ \\
\hline \multirow[t]{2}{*}{ Projected Benefit Obligation (Dec. 31) } & $\underline{\$ 934,000}$ & $\$ 1,107,000$ \\
\hline & $\underline{2006}$ & $\underline{2007}$ \\
\hline Fair Value Plan Assets (Jan. 1) & $\$ 317,000$ & $\$ 518,000$ \\
\hline Contributions & 200,000 & 200,000 \\
\hline Payments & $(11,000)$ & $(15,000)$ \\
\hline Actual Return & $\underline{12,000}$ & $\underline{26,500}$ \\
\hline Fair Value Plan Assets (Dec.31) & $\$ 5 \overline{18,000}$ & $\$ 7 \overline{29,500}$ \\
\hline
\end{tabular}


Dec. 31, 2005

\section{PBO}

FVPA

Funded Status

Unrecognized PSC

Unrecognized Loss

Accrued Pension Cost

$\mathrm{ABO}$

Additional Pension Liability

Total Pension Liability

\section{Pension Expense}

Dec. 31, 2006

$$
\begin{array}{r}
(\$ 934,000) \\
518,000 \\
\hline(416,000) \\
250,000 \\
112,300 \\
\underline{(\$ 53,700)} \\
\hline
\end{array}
$$

$\$ 420,000$

54,500

$\$ 103,000$

$\$ 600,000$
28,300
$\$ 82,000$

Dec. 31, 2007

$(\$ 1,107,000)$

729,500

$(377,500)$

200,000

97,920

$\underline{(\$ 79,580)}$

$\$ 820,000$

10,920

$\$ 90,500$
Service Cost

Interest Cost

Expected Return

Amortization Prior Service Cost

Amortization Gain/Loss

Total Expense $\underline{2006}$

\section{$\underline{2007}$}

$\$ 130,000$

40,500

$(15,300)$

50,000

$\$ 2 \frac{0}{205,200}$
$\$ 150,000$

48,000

$(25,900)$

50,000

3,780

$\$ 225,880$

To apply the new requirements, Accumulated Other Comprehensive Income (AOCI) would be adjusted at December 31, 2006 for all unrecognized amounts at that time. Unrecognized prior service costs of $\$ 250,000$ unrecognized loss of $\$ 112,300$ will be recognized as a liability and reduce AOCI. Any Additional Pension Liability remaining on the books needs to be removed. It is no longer necessary. Exhibit 2 includes the adjusting entries as well as subsequent accounting according to the new requirements.

\section{EXHIBIT 2}

Journal Entries For Transition To SFAS \#158

Annual Pension Expense, And Annual Adjustment, (Example 1)

\section{$\underline{\text { Initial Transition Entries }}$}

Dec. 31, 2006

Dr. AOCI

Cr. Liability

362,300

362,300

Dec. 31, 2006

Dr. Additional Pension Liability
Cr. Deferred Pension Cost

54,500

54,500

\section{$\underline{\text { Entries for Pension Expense }}$}

2007

Dr. Pension Expense

225,880

Cr. Cash

200,000

Cr. Pension Liability

25,880 


\section{Adjusting Entries for Changes}

Dec. 31, 2006

Note that the liability to be reported on the December 31, 2006 Balance Sheet after the adjustments is equal to the underfunded PBO:
Accrued Pension Cost Dec. 31, 2006
$\$ 53,700$
Adjustment to Liability
362,300
Total Pension Liability
$\$ 416,000$

After the initial transition entries, the pension liability account is affected annually by both the recording of pension expense and the recording of any changes in prior service costs and actuarial gains/losses. The entry recording pension expense in 2007 is shown in Exhibit 2. Pension expense, which is not affected by the new rules, is $\$ 225,880$ in 2007. Contributions to plan assets (shown in Exhibit 1) are $\$ 200,000$ each year, resulting in additions to the pension liability of $\$ 25,880$ in 2007 .

The entry for changes in prior service cost and actuarial gains/losses is also shown in Exhibit 2 and is based on the following calculation:

$\begin{array}{lr}\text { Amortization of PSC } & \$ 50,000 \\ \text { Amortization of Loss } & 3,780 \\ \text { Actuarial Gain (Loss) } & 10,000 \\ \text { Actual - Expected Return } & 600 \\ \text { Change in Accounts } & \underline{(\$ 64,380)}\end{array}$

In 2007 , the balance in these accounts decreased by $\$ 64,380$, and an entry is prepared to decrease the liability account and increase Other Comprehensive Income. This entry demonstrates that changes in previously unrecognized amounts, which had minimal effect on the reported liability under current rules, will now flow through OCI and affect the reported liability.

The total effect of the entries made for transition, pension expense, and changes in unrecognized amounts is shown in the reconciliation below. Note that the final liability balance is equal to the underfunded obligation as determined by comparing plan assets with the projected benefit obligation:

Accrued Pension Cost, Dec. 31, 2006

Transition Entry

$\$ 53,700$

362,300

25,880

Journal Entry for Pension Expense

Journal Entry for OCI

Pension Liability Dec. 31, 2005 $\underline{(64,380)}$

$\$ 377,500$

Exhibit 3 illustrates how the changes in prior service costs and actuarial gains/losses would be reported on a Statement of Comprehensive Income. As the $\$ 50,000$ of prior service cost is amortized annually to pension expense, it is reclassified from OCI to Net Income. Removal of the cost would increase OCI. The change in actuarial gain/loss for 2007 has a reclassified amount of $\$ 3,780$ for the amount of loss amortized into pension expense. The change for the year included the gain of $\$ 10,000$ from the actuarial report and the $\$ 600$ excess of actual return on plan assets over expected return. 
EXHIBIT 3

Reporting Of Changes In Delayed Recognitioncosts, (Example 1)

Statement of Comprehensive Income For Year Ended

Net Income

Other Comprehensive Income:

Prior Service Cost Reclassify

Gain (Loss):

During Year

Reclassify

Comprehensive Income $\frac{\text { Dec. 31, } 2007}{\$ X X X}$

$\$ \mathrm{XXX}$

50,000

10,600

$\underline{3,780}$

$\$ \mathrm{XXX}$

\section{Example 2}

Exhibit 4 contains information on another plan under current reporting requirements. Of particular note in this example is the data in 2007. Comparing the plan assets to the projected benefit obligation, we see that the plan is overfunded by $\$ 45,000$ at the end of 2007 . However, under current reporting requirements, the plan would report a liability of $\$ 98,000$ on the balance sheet. As we will see below, the new accounting will result in a $\$ 45,000$ pension asset being reported on the balance sheet.

EXHIBIT 4

Pension Information For Example 2

$\underline{2006}$

Projected Benefit Obligation (Jan. 1)

Service Cost

Interest Cost

Payments

(Gain) Loss

Projected Benefit Obligation (Dec. 31)

Fair Value Plan Assets (Jan. 1)

Contributions

Payments

Actual Return

Fair Value Plan Assets (Dec.31)

$\underline{2006}$

$\$ 1,050,000$

$(22,000)$

$\underline{52,000}$

$\underline{\$ 1,230,000}$

$$
\begin{array}{r}
\$ 1,215,000 \\
130,000 \\
50,000 \\
(22,000) \\
(15,000) \\
\$ 1,358,000 \\
\hline
\end{array}
$$

Dec. 31, 2005

PBO

FVPA

Funded Status

Unrecognized Loss (Gain)

Accrued Pension Cost

$$
\begin{array}{r}
(1,215,000) \\
\underline{1,050,000} \\
(165,000) \\
\underline{30,000)} \\
\underline{(\$ 135,000)} \\
\hline
\end{array}
$$

$\underline{\text { Dec. 31, } 2006}$

$$
\begin{array}{r}
(\$ 1,358,000) \\
1,230,000) \\
(128,000) \\
\underline{8,000} \\
\underline{(\$ 120,000)} \\
\hline
\end{array}
$$

$\underline{2007}$

$\$ 1,358,000$

140,000

65,000

$(25,000)$

$(138,000)$

$\underline{\$ 1,400,000}$

$\underline{2007}$

$$
\begin{array}{r}
\$ 1,230,000 \\
150,000 \\
(25,000) \\
\underline{90,000} \\
\hline 1,445,000 \\
\hline
\end{array}
$$

Dec. 31, 2007

$(\$ 1,400,000)$

$\underline{1,445,000}$

45,000

$(143,000)$

$\underline{(\$ 98,000)}$ 
ABO
Additional Pension Liability
Total Pension Liability

Pension Expense

Service Cost

Interest Cost

Expected Return

Total Expense
$\$ 950,000$

$\$ 135,000$
$\$ 1,100,000$
0
$\$ 120,000$

$\underline{2006}$

$\$ 130,000$

50,000

$(45,000)$

$\$ \underline{\$ 135,000}$
$\$ 1,140,000$

$\$ 98,000$

$\underline{2007}$

$\$ 140,000$

65,000

$(77,000)$

$\$ \$ 128,000$

Entries to be made under the new rules are shown in Exhibit 5.

\title{
EXHIBIT 5
}

Journal Entries For Transition To SFAS \#158

Annual Pension Expense, And Annual Adjustment, (Example 2)

\section{$\underline{\text { Initial Transition Entry }}$}

Dec. 31, 2006

Dr. AOCI
Cr. Pension Asset/Liability

8,000

8,000

\section{Entries for Pension Expense}

2007

\author{
Dr. Pension Expense \\ Dr. Pension Asset/Liability \\ Cr. Cash
}

128,000

22,000

150,000

\section{Adjusting Entries for Changes}

Dec. 31, 2007

The transition entry adjusts AOCI for the $\$ 8,000$ balance in the unrecognized actuarial loss as of December 31, 2006. This entry increases the pension liability account. Pension expense and changes from actuarial loss of $\$ 8,000$ to an actuarial gain of $\$ 143,000$ are recorded for 2007 . The change in the actuarial gain/loss is calculated below:

Actuarial Gain (Loss)
Actual - Expected Return
Change in Account $\underline{2006}$

138,000

13,000

$\$ 151,000$

The 2007 change includes the $\$ 138,000$ gain on the actuarial report and the \$13,000 gain from actual return in excess of expected return. These changes flow through OCI and decrease the pension liability account.

The total effect of the entries made for transition, pension expense, and change in the actuarial gain/loss is shown in the reconciliation below. Note that a pension asset of $\$ 45,000$ would be reported at December 31, 2007 : 
Accrued Pension Cost Dec. 31, 2006

120,000

Transition Entry

Journal Entry for Pension Cost

$(22,000)$

$(151,000)$

$(\underline{\$ 45,000)}$

Exhibit 6 illustrates the changes in actuarial gain/loss on the Comprehensive Income Statement. There were no reclassifications since none of the actuarial gain was included in pension expense.

EXHIBIT 6

Reporting Of Changes In Delayed Recognition Costs, (Example 2)

\section{Statement of Comprehensive Income For Year Ended}

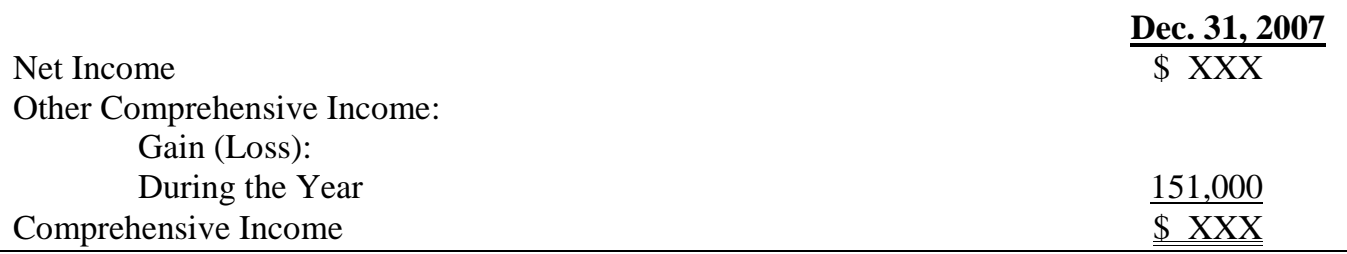

\section{Potential Financial Statement Effects}

This initial phase of the comprehensive project relates to the reporting of the funded status of a defined benefit postretirement plan. SFAS \#158 will have no effect on the calculation Net Periodic Benefit Cost.

Footnoting of the delayed recognition of prior service costs and certain actuarial gains and losses allows for reduced volatility in pension expense but does not reflect the underfunded (overfunded) status of the plan on the financial statements. In order to recognize the funded status of a plan, the new approach requires the changes in the delayed recognition costs to flow through OCI resulting in potential volatility in Comprehensive Income.

The initial application of the new requirements will affect the current amount reported as Pension Liability (Asset). Companies currently footnoting net unrecognized losses will experience a larger liability, while those companies with net unrecognized gains will report a smaller liability or, in some cases like Example 2, an asset. Companies that would be reporting larger liabilities need to be aware of potential problems with debt covenants.

\section{CONCLUSION}

When the FASB developed Statement 87 , it realized that it would be conceptually appropriate to recognize a net pension liability or asset measured as the difference between the projected benefit obligation and the fair value of plan assets. This could have been accomplished either by recognizing all gains or losses in current earnings or by reporting them as other comprehensive income. The FASB felt like those approaches would have been too great a change from the previous accounting for pensions and opted for a more evolutionary improvement by requiring footnote disclosure for these delayed recognition items.

However, many years have past and the FASB has received a tremendous number of requests to address issues related to employers' accounting for defined benefit postretirement plans. The FASB has now completed the initial phase of the comprehensive project with the issuance of SFAS \#158. Delayed recognition costs (credits) and losses (gains) currently disclosed in footnotes will now be reported as other comprehensive income. This will result in a liability (asset) reported on the financial statements that truly reflects the funded status of the plan. 
Journal of Applied Business Research - Second Quarter 2007

Volume 23, Number 2 NOTES 